\title{
Value Addition and Consumers' Satisfaction Compromise: A Case of Raphia Wine Supply Chain in Imo State, Nigeria
}

\author{
N. C. Ehirim \\ Department of Agricultural Economics, \\ Federal University of Technology Owerri \\ R. A. Okere \\ Nigerian Institute for Oil Palm Research (NIFOR). \\ Benin City \\ E. Ikheloa \\ Ambrose Ali University Ekpoma, \\ Edo State
}

\begin{abstract}
Despite increased patronage, stakeholders' participation is fingered in inefficiencies along raphia wine supply chain. The extent which consumers' utility is compromise is beclouded by the margin and no study has established it. Two stage sampling technique was used to draw 32 processor-marketers and 48 wine vendors from the supply markets as well as 91 consumers drawn from the destination market to give 171 sample size. Simple descriptive statistics, marketing margin, budgetary analysis and econometric tools were used in the analyses. Gross margin of $\mathrm{N53.03/litre}$ and N36.51/litre for retailers and processor-marketer respectively, representing $39.8 \%$

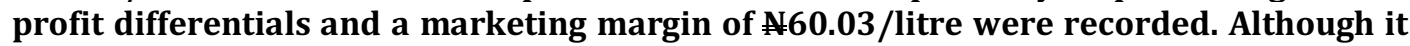
is profitable, value added of $\mathbf{N 1 2 3 . 4 1}$ /litre has $\mathrm{N9.92/litre} \mathrm{of} \mathrm{utility} \mathrm{compromised,}$ hence, increased marketing margin is taking advantage of consumers' preference and utility in the system. Utility compromise is reduced by $5.9 \%$ and $4.8 \%$ with a unit increase in raphia marketing as a major occupation and cost of marketing services but increased by $4.6 \%, 19.5 \%, 2.3 \%$ and $33.5 \%$ with a unit increase in the number of years in the business, distance from the area of supply, co-operative membership and unique selling device employed by the retailer respectively. Majority (94.51\% and $90.0 \%)$ complained that unorganized marketing system especially the lack in unique selling device and poor product standardization characterized by an unorganized utility threshold in the system may be the reason but high patronage is envisaged if $21.98 \%$ consumers who prefer brewed alternative buy local raphia wine. The study recommends a policy that will tackle an organization and standardized market and products to reduce utility compromise in the supply chain.
\end{abstract}

Key words: consumers, satisfaction, compromise, raphia wine, supply chain and value addition

\section{INTRODUCTION}

Transformation of farm produce from one form to the other alone supply chain increases its utility level. According to Ehirim et al. (2007), farm produce is transformed through processing and the value added to it in the process seems to offer better quality and increased consumers' satisfaction. Satisfaction is a judgment that a product or service feature, or the product or service itself, provided (or is providing) a pleasurable level of consumption-related fulfillment, including levels of under or over fulfillment" to the consumer (Oliver, 1996). Consumer's judgment depends on the unit benefit derivable from a unit of that product or service, which 
often measures its value. Traditionally, farm produce are transformed using biological, chemical or physical processes by small holder processors while the distribution is widely done by food vendors across the local markets in Nigeria. Upon transformation of farm produce, consumers placed more value on the product because of the expected benefit from the product. Supply chain provides the needed benefit to increase consumers' satisfaction. Supply chain is a chain of economic activities such as value addition that surrounds farm produce along its distribution to the ultimate consumer. Supply chain must target consumers' preference in terms of product transformation, place and time. A value is added to farm produce when some economic activity performed on them increases the product's utility for the benefit of the consumer. It is that benefit derived from the product when its form changed or title exchanged or it is made available at the right place and time that will account for value placed on the product by the consumer (Anderson and Henselka, 2009). Local beverages industries such as raphia wine industries add value along their supply chain to increase stake holders' benefit. The wine is relatively abundant in few areas of Imo State, and they are made readily available all over the place at the time, and forms that must not compromise satisfaction so that the consumers can get equal value for their money spent. Hence, the consumer places a higher value on raphia wine at any stage in supply chain hoping that the economic activity performed must have increased benefit. Little wonder raphia wine is the most frequently consumed alcoholic beverage (Ezeagu, 2003) despite the local production process. Eyo (2015) opined that the consumption of raphia wine increases between genders. The women who just gave birth use the beverage to stimulate breast milk while the youth and the elderly made the highest patronage.

Raphia wine is a natural beverage of bio-origin, which contains certain level of alcohol, a close substitute to beer and comparatively less expensive (Obahiagbon and Osagie, 2007). It is locally produced in Nigeria in a large quantity and found very popular in the socio-economic life of the coastal dwellers in Nigeria, Ghana, Ivory Coast and other parts of West Africa (Ndom 2003; Li ans Su, 2006 and Ajakaye, 2015). The liquor is a vital factor in marriages and other festivities in all parts of Nigeria (Ugwu and Igboeli, 2009). Raphia wine is a product of raphia palm, tapped from the large inflorescence of the raphia palm. The raphia palm tree has more than 20 species in West Africa. Eight of them; Raphia hookeri, Raphia vinifera, Raphia sudanica,Raphia mannu, Raphia ragalis, Raphia manbillensis Raphia africana, and Raphia longifora are found in Nigeria (Ndom, 2003). Raphia hookeri, is ranked highest in all the raphia palms that produced local wine consumed locally (Karamako et al, 2012). The raphia palm tree, unlike any other palms, flowers once and dies (Okolo and Abigor 2006) but can produce as much as 864-870 litres of fresh concentrated raphia wine in its life time. It reaches maturity of tapping when the spear leaves become shorter and fan like, indicating an initiation stage of the auxiliary inflorescence, which is tapped once in a life time (Ndon, 2003; Okolo and Abigor, 2006). The concentrated sap from a raphia palm flows rapidly at maturity over a short period of 40 to 50 days after which the palm dies (Okolo and Abigor, 2006 and Obahiagbon and Osagie, 2007). Though the period of wine harvest is short-lived relative to other sources of local wine, raphia wine is harvested with a high concentrated of sap (Obire, 2005) usually all year round. Tappers (harvesters) are too conscious of its crucial tapping stage as too early or too late harvest may affect its yield (Ndom 2003). The fresh tapped raphia wine undergoes some economic activities that seem to increase form, time, place and possession utilities while the commercial ones are bottled, preserved and sold in supermarkets or exported to other countries (Ndom 2003). Such economic activity along the supply chain which is expected to increase consumers' satisfaction may be at the consumers' detriment due to the seemingly lost benefit by the consumer. 
Fresh raphia wine with high quality sap has $8.4 \mathrm{gm} / 100 \mathrm{ml}$ of sugar, $0.37 \mathrm{gm} / 100 \mathrm{ml}$ of protein, $0.28 \mathrm{gm} / 100 \mathrm{ml}$ of titrable organic acids and $0.79 \mathrm{gm} / 100 \mathrm{ml}$ of alcohol (Esechie, 1978 ; Stringini et al., 2009 and Ajayi et al., 2011). The wine contains some yeast and bactaria that lives symbiotically, which can initiate fermentation. The quantity of its sugar decreases while its alcohol content increases as the wine ferments with time along the supply chain (Faparusi and Bassier, 1972; Stringini et al., 2009). Noll (2008) noted that the alcohol content of raphia wine increases with the time before and after tapping and the fermentation process if not controlled, will vary widely, hence reducing the quality of the wine. This implies that the expected time utility of raphia wine along its supply chain may increase at the expense of its shelf-life (Adesina, 2012). The fresh raphia wine at any place or time offers the consumer a refreshing taste and better exchange value than the fermented wine. Though accorded a high valued in the areas of relatively scarcity, the exchange process and place utility are very sacrosanct in the marketing system (Njoku, 2000 and Ezealaji, 2011). Hence, despite the seemingly lower quality along the supply chain, it creates the required utility in the marketing system. But this reduced consumers satisfaction despite the increased economic activities by the local producers along the supply chain is a source of concern to value addition policy campaign in the marketing system.

The local technique of production of raphia wine dominates the states because the improved technology requires to preserve the quality of fresh concentrated sap along the distribution chain has not been fully developed in Nigeria (Adakaren, 2014). Ezealaji (2011) observed that the spatiality its production and market, rapid fermentation process and the small scaled feature of stakeholders are fingered in its low marketing efficiency in Nigeria. These features provide the opportunity for the stakeholders to manipulate the quality and quantity of the beverage to their benefit during handling and processing. The resultant quality seems compromised at the detriment of the consumers' satisfaction. Apart from the reduction in its shelf-life as time utility is added, exchange processes may lead to quantity alteration to the benefit of the supplier. Again, the transformation process that should meet a higher consumers' utility level, seems to have the quality compromised as the concentration of the sap and quality are truncated. There seems to be a disconnection between the marketing services provided to the product and the final quality of the product in the marketing system in Imo State. But does the consumer actually know the extent his benefit has been taken away from him? Though the quantity of the product may increase during handling and processing in the supply chain, the quality is highly compromised at a higher marketing cost with a seemingly marketing efficiency in the system. The question is what level of consumer's satisfaction (utility) is compromised for suppliers benefit along the supply chain in Imo State? The level at which the consumers utility is compromised for the benefit of market participants in the raphia wine supply chain in Nigeria and Imo State in particular has not been determined. This study therefore, examined consumers satisfaction (utility) compromise in raphia wine supply cahin, hence determine the factors that account for consumers satisfaction (utility) compromise in raphia wine marketing in Imo state.

\section{CONCEPT OF VALUE ADDITION AND CONSUMERS' SATISFACTION COMPROMISE IN RAPHIA WINE SUPPLY CHAIN}

Advanced or traditional technologies are commonly used when value is addition to farm produce is needed (Obahiagbon, 2009; Bartle, 2012). Although the technologies that improve handling, preservation, dehydration and drying, freezing, packaging and labelling, etc. are imperative in attaining higher consumer utility level of farm produce, Okolo Abigor, (2007) opined that such technologies are not within the reach of majority of raphia wine marketers in Nigeria. Acquisitions of capital, tools, management skills and strategies as well as technical empowerment are necessary for improved technical efficiency in the marketing system. An 
addition to machines or management operations for efficient value addition to agricultural products is called market investment. In raphia wine processing and distribution, advanced technology has not been fully developed in Nigeria, but the traditional technology has gained wide acceptance in the local market and has improved the marketing performance of the product in the local markets. Although the traditional technology may not offer the required level of quality output compared to the commercial production of safe food, market stakeholders still manipulate the available local facilities to their common benefit (Ehirim, 2010). Any traditional technology that increases the quality and safety of raphia wine will also add to consumers' value for the product and enhances consumer' willingness to pay than not having it (Ehirim et al., 2007).

According to Ehirim et al. (2007), consumers' value for safe and quality food is sacrosanct just as consumers' preference is imperative in analysing his need assessment by the supplier of that product. The consumer's value for safe and quality product depreciates when the quality of the product is compromised (Ehirim et al., 2010). This is because, the consumer is obviously rational. He expects a higher benefit from a unit quantity of the quality product he will consume. Therefore, his utility potential for high quality of a product is expected to trigger his willingness to pay a higher amount than not having that product (Ehirim at al., 2010). In the same way, consumer preference is important to the producer or supplier of the product, hence he embarks on the necessary need assessment of a consumer. The case of raphia wine produced locally is different because the expected value addition to the product often compromise consumers' utility. Ali (2008) and Ouaba et al (2012) individually noted that the market stakeholders of raphia wine are illiterates and the industry is not furnished with the improved technology to retain the quality and safety of the sap as economic activities are performed on the product along the distribution chain. According to Ouaba et al. (2012) the tapping of raphia wine requires experts and skill arts developed by local small holder wine tappers. Their skillful art may allow the accumulation of sap with sweet taste, otherwise it will transform to alcohol by some bacteria in few hours.

Furthermore, if the usual time utility that seems to add value to raphia wine is anything to go by, the quality will further reduce to acetic and lactic acids, thus making the sweet raphia wine taste to sour taste within 24 hours. This means that the economic activities to a unit quantity of fresh concentrated raphia wine along the supply chain might lead to a reduction in its quality as the sweet concentrated sap turns sour in time and space. Hence, the quality of the product is compromised along the distribution chain (Omofonmwan, 2013). Gross marketing inefficiency may result to consumers sacrificing their satisfaction. The sacrifice made by consumers for a unit quantity of the product owing to some sharp practices and market inefficiency along the supply chain is in form of consumers' satisfaction (utility) compromise. According to Ehirim at al. (2007), the satisfaction compromised may not affect the suppliers' net return as consumers may not take into consideration these factors that played out along the supply chain and their socio-economic and the market disposition may be a strong limitation. But certainly, consumers' value for the product may reduce in a very long-run (Scarbotough and Kydd, 1992). In most cases, ignorance may have overwhelming influence on their consumption especially in places where the product is scarce (Ehirim, 2010). According to Aiyeloja (2014) demographic factors contributed to raphia wine consumption and whatever is done in the supply chain, stakeholders level of profit will not altered. Therefore, reduction in quality due to handling of farm produce may affect the product safety, but the returns from such marketing activities continue to increase (Ehirim et al., 2007 and Ehirim, 2010). Though such need assessment is done at a certain marketing cost that ensures optimum marketing efficiency, optimal consumers utility level is compromised. The utility function of the consumer and revenue maximization of suppliers are usually in a conflict at the detriment of former. A wide 
gap exist between what the consumer wants to maximize and what the supplier of raphia wine wants to maximize in the system. Optimum efficiency in the supply chain exists where a consumer's utility function is maximized and the supplier attains maximum total revenue.

The consumers utility function $\{\mathrm{U}\}=\mathrm{f}\left\{\mathrm{P}_{\mathrm{q}} \mathrm{Q}_{f}\right\}$ and The revenue function $\left.\{\mathrm{Sq}\}=\mathrm{f}_{\mathrm{P}} \mathrm{P}_{\mathrm{s}} \mathrm{Q}_{\mathrm{q}}\right\}$

Therefore; Gross margin $=\sum_{n=1}^{\infty}\left(\mathrm{P}_{\mathrm{s}} \mathrm{Q}_{\mathrm{f}}-\mathrm{P}_{\mathrm{q}} \mathrm{Q}_{\mathrm{f}}\right)$ and the marketing margin $=\sum_{n=1}^{\infty}\left(P_{s}-\mathrm{P}_{\mathrm{q}}\right)$

Where;

$\mathrm{P}_{\mathrm{q}}=$ Unit price of the fresh raphia wine before value addition

$\mathrm{Q}_{f}=$ Quantity of fresh raphia wine of the supplier expected to maximize the consumers utility

$\mathrm{P}_{\mathrm{s}}=$ Unit price of the raphia wine after value addition

$\mathrm{Q}_{\mathrm{q}}=\mathrm{Quantity}$ of raphia wine sold to consumer after value addition, expected to maximize suppliers revenue.

$\mathrm{Sq}=$ Total Revenue the suppliers aim at getting

$\mathrm{U}=$ consumers utility level the consumer seeks to get

The value of consumers' utility the consumers seeks from a unit quantity of the product $\{U\}$ and the total revenue expected from the supplier of the product after some marketing services $\{\mathrm{Sq}\}$ are expected to be equal if the transfer of energy are equal during the product transformation. But given that the need assessment of consumer by the supplier result to utility maximization and the suppliers total revenue maximization after value addition is not questionable, more consumers utility is thus compromised.

Therefore; at equal energy level;

$\sum_{i=1}^{n}(\mathrm{~S})_{\mathrm{q}}=\sum_{i=1}^{\infty}(\mathrm{U})$

Then the Total Value addition by suppliers to raphia palm sold $=\sum_{i=1}^{n}\left(P_{s} Q_{q}-P_{q} Q_{f}\right)$

But the normal profit made for the product sales $=\sum_{i=1}^{n}\left(\mathrm{P}_{\mathrm{s}} \mathrm{Q}_{\mathrm{f}}-\mathrm{P}_{\mathrm{q}} \mathrm{Q}_{\mathrm{f}}\right)$

Therefore;

Consumers' utility compromise $\left\{\mathrm{C}_{\text {com }}\right\}=\sum_{i=1}^{\infty}\left(\mathrm{P}_{\mathrm{s}} \mathrm{Q}_{\mathrm{q}}-\mathrm{P}_{\mathrm{q}} \mathrm{Q}_{\mathrm{f}}\right)-\sum_{i=1}^{\infty}\left(\mathrm{P}_{\mathrm{s}} \mathrm{Q}_{\mathrm{f}}-\mathrm{P}_{\mathrm{q}} \mathrm{Q}_{\mathrm{f}}\right)$

\section{METHODOLOGY}

The research would be conducted in Imo State Nigeria, which is located in the South Eastern part of Nigeria with a total land area of 5,530 sqkm${ }^{2}$. The state lies between latitude $4^{0} 45^{\mathrm{I}} \mathrm{N}$ and $7^{0} 15^{\mathrm{I}} \mathrm{N}$ and Longitude $6^{0} 50^{\mathrm{I}} \mathrm{E}$ and $7^{0} \mathrm{25}^{\mathrm{I}} \mathrm{E}$. The State shares boundaries with Abia State to the East, Delta State to the West, Rivers State to the South and Anambra State to the North (ISSYB, 2004). The State has a population of about 3,934,899 persons comprising of about 1,902,613 males and about 2,032,286 females (NPC, 2006). The area is made up of 27 local government areas divided into three agricultural zones namely Owerri (11), Orlu (10) and Okigwe (6).

Farming is the predominant occupation of the rural inhabitants though there are some pockets of traders across the state. Almost all the families in the area farm either as a primary or secondary occupation. The region is rich in natural resources such as crude oil, limestone, lead, zinc. Economically exploitable flora like the Iroko, Mahogany, Obeche, Bamboo, Rubber and Oil and raphia palm trees are predominant in the area. The main crops grown in the area by arable crop farmers practicing sustainable soil management techniques include cassava, cocoyam, yam, maize, okoro, garden egg and vegetable etc. While livestock reared include goat, sheep, 
poultry, pigs etc, but in small-scale basis (MANR, 1998; Imo ADP, 2013). Other economic activities include trade. Raphia palm production is though not evenly distributed throughout the state, is concentrated in the places with pockets of flowing natural drainage, which offers ecological advantage for its growth. The study targeted raphia wine sellers, hence the market stakeholders comprising of the processor-marketers/wholesalers and retailers of raphia wine who formed the respondents of this study. The dominant production and marketing local government areas (LGAs) of raphia wine are Ngor-Okpala, Aboh, Ezinihite and Ahiazu Mbaise LGAs while Owerri municipal, Owerri west and Nwangele LGAs were the destination region because of the predominant retail outlets across in those locations.

A two stage sampling techniques was used in this study. First, was purposive selection of a local supply market within a local government area (LGA) know for their predominant raphia wine production with a corresponding sparsely distributed retail outlets from another local government Nkwoala market in Ngor-Okpala LGA with their corresponding retail outlets (destination market) in Owerri municipal linked by means of patronage were purposively selected. The choice two LGA's with their market locations was to efficiently trace the line of marketing activities performed on the same products from supply region within the same local market down to the destination retail outlets along the supply chain. The predominant activities of market participants in the two markets within the two local government areas informed the selection of these two markets at this stage. In the second stage, a snow-ball sampling techniques was used to draw 60 producer-marketers from Nkwoala market in NgorOkpala LGA and their corresponding raphia wine retailers located in Owerri municipal linked by common patronage. The study found only 32 of the response from the processor-marketers useful. This is because of the assumption that raphia wines produced in the same ecological zone area are undifferentiated and any differences in the handling processes on the product within the selected local market supply may be very negligible.

Difference in utility derived per unit product consumed may be due to marketing activities along the supply chain. Amoa-Awua et al. (2007) and Ouoba et al. (2012), differently argued that product handling may not stop at the supply markets but can trickle down to the ultimate consumer through the retail vendors' activities in the destination markets. This proposition does not differ with the principle that differentiation in raphia palm variety may alter both the product quality and quantity. Hence, the differences in tastes, concentration, colour and quantity of the same product in the spatial markets is entirely blamed on stakeholders' participation in the food value chain system. Ehirim (2010) opined that any deviation from quality of a product along the supply chain may be as a result of inefficiency in food supply system with the participants in the supply chain seriously fingered. In actual sense, the raphia wine supply have value added at different nodes of its supply chain that target consumers' preferences, thus discrepancies in colour, taste, concentration and even quantity as the product moves to the final consumers expands the market imperfection.

Furthermore, the raphia wine vendors in the destination markets linked by the processormarketers were drawn using snow-balling techinques. The vendors handling, transportation and exchange processes as well as other economic activities continued to vary along the supply chain depending on their different socio-economic disposition. A total of 60 raphia wine retail vendors were administered with a well structured questionnaire but 48 responses were found useful for the study. The survey found a total of 80 raphia wine traders across the state as very useful for data analysis. In the same manner, a sample 90 consumers were drawn from the retail vendors in Owerri Municipal Council with 67 responses found useful for the study. 
The cost of fresh raphia wine was estimated from the number of stands a tapper (processor) could harvest per week as the supply market usually run on each 8 market days. The raphia palms are leased out to processor (lessee) or the farmer (lessor) can tap it by himself. However, the mean shadow price of leasing a stand of raphia wine is $\$ 200.00 /$ stand for a period of only 8 days when another market is opened in the supply market. The shadow price for the leasing raphia palm was used to estimate the cost of the fresh raphia wine per period the leasing agreement was taken. A straight line method was used to estimate the depreciation of all fixed input used while interest on borrowed capital were estimated using simple interest method of estimation. Other estimates were made per unit quantity (litres) since the product was sold in gallons (5-litre jar). The unit market prices vary slightly within the same market (both in supply and destination markets) and the mean unit price was used for the estimation. However, the value of unsold product both in supply and destination markets were very negligible and were not included in the analysis. The data were collected between June and October 2017.

The study was analyzed using both descriptive and econometric tools. The socio-economic features of the wine sellers were analysed using a simple descriptive statistics.

The expected consumer utility and the seller total revenue are expressed as;
$\mathrm{U}=\mathrm{P}_{\mathrm{q}} \mathrm{Q}_{f}$
3.1
$\mathrm{Sq}=\mathrm{P}_{\mathrm{S}} \mathrm{Q}_{\mathrm{q}}$

Processors profit $\left(\mathrm{P}_{\pi}\right)=\left\{\mathrm{P}_{\mathrm{q}} \mathrm{Q}_{\mathrm{f}}-\mathrm{P}_{\mathrm{cp}} \mathrm{Q}_{\mathrm{f}}\right\} \quad=\quad \mathrm{Q}_{\mathrm{f}}\left\{\mathrm{P}_{\mathrm{q}}-\mathrm{P}_{\mathrm{cp}}\right\}$

Retail Profit $\left(\mathrm{R}_{\pi}\right)=\left\{\mathrm{P}_{\mathrm{s}} \mathrm{Q}_{\mathrm{q}}-R_{c p}\right\}$

Profit Differential $\left\{\pi_{D}\right\}=\mathrm{R}_{\pi}-\mathrm{P}_{\pi}$

$$
\left.=\left\{\mathrm{P}_{\mathrm{s}} \mathrm{Q}_{\mathrm{q}}-R_{c p}\right\}-\mathrm{Q}_{\mathrm{f}}\left\{\mathrm{P}_{\mathrm{q}}-\mathrm{P}_{\mathrm{cp}}\right\}\right\}
$$

Marketing Margin $\left\{\mathrm{M}_{\mathrm{m}}\right\}=100\left\{\sum_{n=1}^{n}\left(P_{s}-\mathrm{P}_{\mathrm{q}}\right) / \mathrm{P}_{\mathrm{s}}\right.$

Value added ( $\left.\mathrm{V}_{\text {added }}\right)$ is the difference in the value of the product in the hand of the retailer and the value of the product in the hand of the processor.

$\mathrm{V}_{\text {added }}=\sum_{i=1}^{n}\left(\mathrm{P}_{\mathrm{s}} \mathrm{Q}_{\mathrm{q}}-\mathrm{P}_{\mathrm{cp}} \mathrm{Q}_{\mathrm{f}}\right)$

Therefore, the consumers' utility compromise $\left\{\mathrm{C}_{\text {com }}\right\}$ is expressed as;

$\left\{\mathrm{C}_{\mathrm{ucom}}\right\}=\sum_{i=1}^{n}\left(\mathrm{P}_{\mathrm{s}} \mathrm{Q}_{\mathrm{q}}-\mathrm{P}_{\mathrm{cp}} \mathrm{Q}_{\mathrm{f}}\right)-\sum_{i=1}^{n}\left(\mathrm{P}_{\mathrm{s}} \mathrm{Q}_{\mathrm{f}}-\mathrm{P}_{\mathrm{q}} \mathrm{Q}_{\mathrm{f}}\right)$

Where;

$\mathrm{P}_{\mathrm{q}}=$ Unit price of the fresh raphia wine before value addition (unit producer Price) in naira

$\mathrm{Q}_{f}=$ Quantity of fresh raphia wine at the supply stage to maximize the consumers utility in litres.

$\mathrm{Q}_{\mathrm{q}}=\mathrm{Quantity}$ of raphia wine that finally sold to consumer after value addition in litres.

$\mathrm{P}_{\mathrm{S}}=$ Unit price of the raphia wine after value addition (unit retail price) in naira.

$\mathrm{P}_{\mathrm{cp}}=$ Processors marketing cost in naira

$R_{c p}=$ Retailers marketing cost in naira

$\mathrm{P}_{\pi}=$ Processors profit in naira 
$\mathrm{R}_{\pi}=$ Retail Profit in naira

$\pi_{D}=$ Profit Differential between retailers and processors along the supply chain in naira.

$\mathrm{V}_{\text {added }}=$ Total value added to the product

$\mathrm{M}_{\mathrm{m}}=$ Marketing margin

$\mathrm{C}_{\mathrm{ucom}}=$ consumers' satisfaction (utility) compromise

The factors affecting the consumer satisfaction (utility) compromise in raphia wine supply chain are isolated using an ordinary least square regression analysis. The consumer satisfaction (utility) compromise model is fitted into four functional forms of linear, CobDouglas, exponential and semi-log models and the lead equation was obtained using the following criteria; the model with the best fit base on the highest co-efficient of multiple determination and F-statistics, the model with the highest number of significant explanatory variables and the model with the highest number of consistent a priory expectation base on the signs of the explanatory variables. The model is implicitly expressed as;

$\mathrm{C}_{\text {ucom }}=f\left(\mathrm{X}_{\mathrm{i}} \beta+\mathrm{U}_{\mathrm{i}}\right) \quad$ as $\mathrm{i}=1,2,3, \ldots 10$

Where:

$\mathrm{C}_{\mathrm{ucom}}=$ Consumers' satisfaction (utility) compromise in naira

$\beta=$ Vector of unknown coefficients

$\mathrm{U}_{\mathrm{i}}=$ Error term, assumed to be independently distributed with mean zero and a variance

$\mathrm{X}_{\mathrm{i}}=$ Vector of independent variables; which include;

$\mathrm{X}_{1}=$ Age of trader (years)

$\mathrm{X}_{2}=$ Sex of trader (male = " 1 ", Otherwise "0")

$\mathrm{X}_{3}=$ Level of formal Education of the trader (No. of years spent in school)

$\mathrm{X}_{4}=$ Household size (No. of persons per Catherine arrangement of the trader)

$\mathrm{X}_{5}=$ Trading as a major occupation (Trading as the major occupation = " 1 " otherwise " 0 ")

$\mathrm{X}_{6}=$ Trading Experience (years)

$\mathrm{X}_{7}=$ Total marketing cost (in Naira)

$\mathrm{X}_{8}=$ Distance from the place of purchase or tapping of the product (in kilometers)

$\mathrm{X}_{9}=$ Availability of any preservation device (dummy = yes " 1 " otherwise " 0 ")

$\mathrm{X}_{10}=$ Unique selling proposition; labels or any safety net for the product (dummy = yes " 1 " otherwise "0")

\section{RESULTS AND DISCUSSION}

Distribution of raphia wine traders base on some selected socio-economic feature

Table 1 is the descriptive statistics of the socio-economic features of the raphia wine sellers in Imo State. 
Table 1: Socio-economic characteristics of raphia wine traders and consumers in Imo State

\begin{tabular}{lcccc}
\hline \multirow{2}{*}{ Variables } & \multicolumn{2}{c}{ Raphia wine traders } & \multicolumn{2}{c}{ Raphia wine consumers } \\
& Frequency & Percentages (\%) & Frequency & Percentages (\%) \\
\hline Age (years) & 9 & & & \\
$20-30$ & 13 & 11.25 & 12 & 13.18 \\
$31-40$ & 17 & 21.25 & 8 & 8.97 \\
$41-50$ & 22 & 27.25 & 16 & 25.27 \\
$51-60$ & 19 & 23.75 & 32 & 17.58 \\
Above 60 & $\mathbf{8 0}$ & $\mathbf{1 0 0 . 0 0}$ & $\mathbf{9 1}$ & $\mathbf{1 0 0 . 0 0}$ \\
Total & & & & \\
Formal Education Attainment (years) & 32 & 40.00 & 39 & 42.86 \\
Non-formal Education & 22 & 27.50 & 30 & 32.97 \\
Primary Education & 18 & 22.50 & 10 & 10.99 \\
Secondary Education & 8 & 10.00 & 12 & 13.19 \\
Tertiary Education & $\mathbf{8 0}$ & $\mathbf{1 0 0 . 0 0}$ & $\mathbf{9 1}$ & $\mathbf{1 0 0 . 0 0}$ \\
Total & & & & \\
Trading/Work Experience (years) & 12 & 15.00 & 18 & 19.78 \\
$1-5$ & 18 & 22.50 & 23 & 25.27 \\
6-10 & 35 & 43.73 & 15 & 16.48 \\
11 - 15 & 15 & 18.75 & 35 & 38.46 \\
16-20 & $\mathbf{8 0}$ & $\mathbf{1 0 0 . 0 0}$ & $\mathbf{9 1}$ & $\mathbf{1 0 0 . 0 0}$ \\
Total & & & & \\
Gender (dummy) & 30 & 37.50 & 69 & 75.82 \\
Males & 50 & 62.50 & 22 & 24.18 \\
Female & 80 & 100.00 & 91 & 100.00 \\
Total &
\end{tabular}

Source: Field Survey 2018

The result of the age distribution traders shows that $11.25 \%$ of the traders are with the age limit of 21-30 years of age and $16.25 \%$ of them are with $31-40$ years of age. $21.25 \%$ of them are 41 - 50 years. The aggregate proportion of active age category is $49.0 \%$, indicating that few traders are in their active years. Again, few young traders who are within their active age categories took up the trade. Unaeze et al. (2009) opined that active youths are constantly migrating to urban areas, thus reducing the number of young wine tappers and marketers in Nigeria. The result shows that majority (22.25\%) of the traders are within the age bracket of 51 - 60 years while $23.75 \%$ of them are above 60 years. This shows that the stakeholders in raphia wine marketing a little above the active age. The business is carried out mainly by old traders who are either processors marketers or marketers.

In a similar manner, majority (35.16\%) of the consumers are relatively old of above 60 years of age while only few of them (8.97\%) are within young age of 31 to 40 years of age. It could be deduced from this result that the market stakeholders are old citizens who attitude towards risk is reduced. Raphia wine production and marketing according to Ugwu and Igoeli (2009) are associated with high risk of wading through the swamp and semi-swampy ecosystem, climbing, tapping the wine and bringing through the thick swampy rainforest to market, making place utility very difficult and risky for old stakeholders. Again, the marketing system may be lacking some young active stakeholders who will replace the old stakeholders in the marketing system.

Base on their level of formal education attainment, majority $40.0 \%$ and $42.86 \%$ of traders and consumers had non-formal education. Also about $27.50 \%$ and $32.97 \%$ of the traders and consumers respectively had only primary education while only few $(10.00 \%$ and $13.19 \%)$ of them had tertiary education qualifications. This shows that the level of education attainment of both traders and consumers is quite low. This result collaborate the observation of Ali (2008) 
and Ouaba et al (2012) who separately noted that the educational status of local wine dealers is low and their lliteracy level may not encourage high technical skills required to improve the form utility in the system. This finding suggests that effort should be made by the stakeholders to enhance consumers' utility and preference by ensuring that skill to achieve food safety, preservation of the product over time and space in the area is put in place.

The distribution of traders based on their years of trading experience in raphia wine marketing in this study shows that $15.0 \%$ of the readers have less than 5 years of experience in the trade while $22.50 \%$ of the have between 5-10 years of experience in the trade. Majority (43.75\%) of them have relatively higher number of trading experience of between 11-15 years while about $18.75 \%$ of the have more than 15 years of trading experience in raphia wine trade. The high number of years of being in the business suggests that local traders may have mastery of the skill arts in processing and distributing the commodity across the state. According to Nasiru et al. (2006), expertise and mastery are attained through experience, which is known to be the best teacher. The mastery of business skill arts may suggest an approach the suppliers use to attain higher returns and as well as assessing consumers need and attaining consumer preference may. The distribution based on sex shows that majority $(67.50 \%)$ traders were mainly male while $37.5 \%$ them are females. This finding collaborates Nwaibo et al. (2012) and Adinya (2008) that male marketers dominate local wine marketing in Nigeria. This result shows that the business is associated with male farmers. Tapping of the wine fall within male gender and the female gender are mainly engaged in distribution and other handling techniques in the distribution chain.

\section{ESTIMATION OF COST AND RETURNS, MARKETING MARGIN VALUE ADDITION AND CONSUMER COMPROMISE OF RAPHIA WINE IN IMO STATE}

The result of the Cost and Returns and marketing margin of raphia wine marketing in Imo State is shown in Table 2 below 
Table 2 Cost and Returns, Marketing Margin. Value addition and Consumers' Satisfaction Compromise in Imo State

\begin{tabular}{|c|c|c|c|c|}
\hline \multirow{11}{*}{$\begin{array}{l}\frac{9}{8} \\
\frac{8}{8} \\
\frac{8}{8}\end{array}$} & Variable & $\begin{array}{l}\text { Mean } \\
\text { Quantity }\end{array}$ & Detail & $\begin{array}{l}\text { Amount } \\
(\mathrm{N}) / \text { litre }\end{array}$ \\
\hline & Raphia wine sold $\left(\mathrm{P}_{\mathrm{q}}\right)$ & $\begin{array}{l}\text { Stage I } \\
582 \text { litres } \\
\text { (Qf) }\end{array}$ & 582 litres@ $\$ 80.30 /$ litre $\left(\mathrm{P}_{\mathrm{q}}\right)$ & 80.30 \\
\hline & Market levies & \$500/week & N500 per stand per week & 0.86 \\
\hline & Wage & 5 mandays & 5mandays @ $1800 /$ manday & 6.87 \\
\hline & Depreciation & - & - & 4.02 \\
\hline & Interest & $7.50 \%$ & @ 7.5\% interest rate/week & 12.89 \\
\hline & Cost of processing & 582 litres & 52 litres @ $\$ 7.00 /$ litre & 0.62 \\
\hline & Transportation & 582 litre & 582 litres @ $\$ 1.70 /$ litre & 1.70 \\
\hline & Cost of fresh wine & 582 litres & $\begin{array}{c}582 \text { litres from } 49 \text { stands/week @ } \\
\text { N200.00/stand }\end{array}$ & 16.83 \\
\hline & Marketing Cost $\left(\mathrm{P}_{\mathrm{cp}}\right)$ & 582 litres & 582 litres & 43.79 \\
\hline & Processor Profit $\left(\mathrm{P}_{\pi}\right)$ & $\begin{array}{l}\text { 582litres } \\
\text { Stage II }\end{array}$ & - & 36.51 \\
\hline \multirow{11}{*}{$\begin{array}{l}0 \\
0 \\
0\end{array}$} & Raphia Wine sold $\left(\mathrm{P}_{\mathrm{s}}\right)$ & $\begin{array}{l}987 \\
\text { litres }\left(\mathrm{Q}_{\mathrm{q}}\right)\end{array}$ & 987 litres@ @133.33/litre & 133.33 \\
\hline & Wage & $\begin{array}{l}30 \\
\text { mandays }\end{array}$ & @ $\$ 233.33 /$ manday & 10.13 \\
\hline & Market levies & \$500/week & - & 0.86 \\
\hline & Raphia wine bought & 582 litres & 582 litres@ @80.30/litre & 80.30 \\
\hline & Depreciation & - & & 6.73 \\
\hline & Processing & 582 litres & 582 litres @ & 8.30 \\
\hline & Transportation & 582 litres & 582 litres @ $\$ 3.20$ litre & 1.89 \\
\hline & Rent & Monthly & @ \$4,265/week & 4.69 \\
\hline & Interest & $7.5 \%$ & $7.5 \%$ interest rate/week & 11.40 \\
\hline & Marketing Cost on $\left(\mathrm{R}_{\mathrm{cp}}\right)$ & & 582 litres bought & 124.3 \\
\hline & Retail Profit $\left(\mathrm{R}_{\pi}\right)$ & & \#60.03/litre & \\
\hline \multirow{5}{*}{ 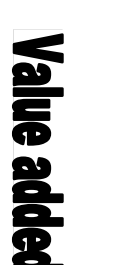 } & Marketing Margin $\left(\mathrm{P}_{\mathrm{s}}-\mathrm{P}_{\mathrm{q}}\right)$ & & \$53.03/litre & \\
\hline & Profit Differentials $\left(D_{\pi}\right)$ & & \#23.52/litre & \\
\hline & Value Added $\left(P_{s} Q_{q}-P_{c p} Q_{f}\right)$ & & $\$ 123.41$ /litre & \\
\hline & Consumer satisfaction & & \#9.92/litre & \\
\hline & $\begin{array}{l}\text { (utility) compromised } \\
\left(\mathrm{C}_{\text {com }} \text { Ps - V Vadded }\right.\end{array}$ & & & \\
\hline
\end{tabular}

\section{Source: Field Survey 2018}

The two-stage supply chain showed that value was added to the product at both stages. The processor-marketers stage has a total marketing cost of $\$ 43.79 /$ litre for mean quantity of 582 litres sold per market session. This comprises of $\$ 0.62$ /litre and $\$ 1.70 /$ litre of processing and transportation cost or $1.42 \%$ and $3.87 \%$ of the marketing cost at that stage respectively. Other cost implications at this stage of supply chain include; the market levies (N0.86/litre), wages

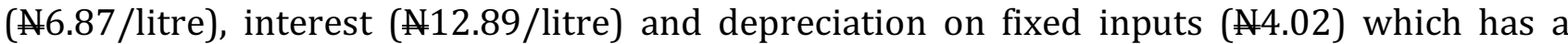
proportion of $1.96 \%, 15.7 \% 29.4 \%$ and $9.16 \%$ respectively. The cost of fresh palm wine is $\$ 16.83$ /litre, which is about $38.4 \%$ of the marketing cost. The result shows that interest on borrowed capital dominated the total marketing cost after the cost of fresh raphia wine along this stage of supply chain. Raphia wine is sold at $\$ 80.30 /$ litre and the processor marketers recorded a total profit after sales of $\$ 36.51 /$ litre in the supply market.

The second stage records the marketing activities in the destination market. This stage consists of mainly the retail vendors who usually sold to the consumers, they have direct contact with the consumers and can identify consumers' preference for better raphia wine in the supply chain. This market recorded a mean sale of 987 litres of the product implying that the mean 
quantity bough has increased by $69.6 \%$ of the mean quantity bought from the supply market. This increase in quantity part of the economic activities performed along the supply chain. Consumers may or may not be aware of these practices because it is the part of value addition to the product along the supply chain.

It could be seen from the result that total marketing cost is about $\$ 124.30 /$ litre with the cost of fresh raphia wine dominating by $64.6 \%$ followed by interest with $\$ 11.40 /$ litre or $9.1 \%$ of the mean marketing cost at the destination market. The mean revenue and profit generated at the destination stage is $\$ 133.33 /$ litre and $\$ 60.03 /$ litre respectively. There is a wide profit differential at the different market along the supply chain. The profit differential is N23.52/litre, which is about $64.4 \%$ of the profit made at the supply market. This shows that marketing activities at destination market yields higher returns than the supply market. This could be due to the spatiality as well as the level of value addition to a unit quantity of the product at the destination market. The marketing margin however, is $\$ 53.03 /$ litre showing that the two stages of supply chain must have contributed as high as $66.4 \%$. This means that cost of providing marketing services and the normal profit of the retailer is about $66.4 \%$ of the purchase price. Scarborough and Kydd (1992) opined that a high marketing margin may result to low profit for the retailer as the cost of performing marketing services or economic activity along the supply chain may be very large. This is not the case with raphia wine retail vendors in the state as their profit margin is over $39.8 \%$ greater than that of the processor-marketers in the area. This could be due to gross marketing inefficiency resulting to consumers sacrificing their satisfaction. This sacrifice made by consumers for a unit quantity of the product is called consumers satisfaction (utility) compromise. The mean consumer satisfaction (utility) compromise is estimated as $\mathrm{N9.92/litre} \mathrm{along} \mathrm{the} \mathrm{supply} \mathrm{chain.} \mathrm{This} \mathrm{is} \mathrm{a} \mathrm{pseudo} \mathrm{utility} \mathrm{charge}$ on the consumer. It could be that the consumer must have made an extra $\$ 9.92$ /litre as excess payment, which cannot account for as utility added to the product. The consumer actually felt that this amount is included in the value added to the product by bringing the product closer home and such pseudo utility charge must have a negative effect on marketing efficiency (Scarborough and Kydd, 1992).

\section{FACTORS OF CONSUMER SATISFACTION (UTILITY) COMPROMISE IN RAPHIA WINE SUPPLY CHAIN}

The result shows the estimates of the four functional forms. The co-efficient of multiple determination for linear, semi-log, double log and exponential are presented as $0.663,0.587$, 0.604 , and 0.543 respectively. In the same way, the F-statistic for the four functional forms is $7.279,5.258,5.645$, and 4.396 respectively. The linear model have the highest co-efficient of multiple determination. 


\section{Determinants of value addition to raphia wine distribution and marketing in Imo State}

Table 3. Regression Estimates of factors affecting consumers satisfaction (utility) compromise in raphia wine supply chain in Imo State

\begin{tabular}{|c|c|c|c|c|c|c|c|c|}
\hline \multirow[b]{2}{*}{ Variables } & \multicolumn{2}{|l|}{ Linear Model } & \multicolumn{2}{|c|}{ Semi Log Model } & \multicolumn{2}{|c|}{ Cob-Douglas Model } & \multicolumn{2}{|c|}{ Exponential Model } \\
\hline & Co-efficient & $\begin{array}{l}\text { /t- } \\
\text { value/ }\end{array}$ & Co-efficient & $\begin{array}{l}\text { /t- } \\
\text { value/ }\end{array}$ & Co-efficient & $\begin{array}{l}\text { /t- } \\
\text { value/ }\end{array}$ & Co-efficient & $\begin{array}{l}\text { /t- } \\
\text { value/ }\end{array}$ \\
\hline Constant & $193.26^{* * *}$ & 35.24 & $6.463^{* *}$ & 2.11 & $3.192^{* * *}$ & 2.907 & $41.664^{* * *}$ & 4.760 \\
\hline (Std error) & 5.476 & & 3.063 & & 1.098 & & 8.753 & \\
\hline Age & -0.003 & 0.017 & $-0.814^{* * *}$ & 3.142 & $-0.511^{* * *}$ & 3.255 & $-5.832^{* *}$ & 2.159 \\
\hline (Std error) & 0.176 & & 0.259 & & 0.157 & & 2.701 & \\
\hline Sex & 0.156 & 0.067 & $0.006^{* *}$ & 2.222 & 0.091 & 0.450 & 2.861 & 1.048 \\
\hline (Std error) & 2.328 & & 0.0027 & & 0.202 & & 2.730 & \\
\hline Formal Education & 0.007 & 0.0009 & 0.053 & 0.045 & -0.008 & 0.148 & $7.31 \times 10^{-}$ & 3.263 \\
\hline Attainment & 7.778 & & 1.184 & & 0.054 & & $2^{* * *}$ & \\
\hline (Std error) & & & & & & & $2.24 \times 10^{-2}$ & \\
\hline House Hold Size & -1.579 & 0.996 & -0.334 & 0.286 & $-0.007 * * *$ & 3.497 & -0.644 & 0.979 \\
\hline (Std error) & 1.585 & & 1.167 & & 0.002 & & 0.658 & \\
\hline Trading as major & $-5.782^{* *}$ & 2.338 & 0.432 & 0.119 & $0.063^{* * *}$ & 4.846 & -15.471 & 1.561 \\
\hline $\begin{array}{l}\text { Occupation } \\
\text { (Std error) }\end{array}$ & 2.473 & & 3.630 & & 0.013 & & 9.911 & \\
\hline Trading Experience & $4.678^{* * *}$ & 6.778 & $-0.798^{* *}$ & 2.411 & $-0.010^{* * *}$ & 3.333 & $-0.457^{* * *}$ & 11.994 \\
\hline (Std error) & 0.6901 & & 0.331 & & 0.003 & & 0.0381 & \\
\hline Retail Total marketing & $-4.781^{* *}$ & 2.337 & $-2.01 \times 10^{-}$ & 2.510 & $-0.096^{* *}$ & 2.133 & $4.441 \times 10^{-}$ & 3.698 \\
\hline Cost & 2.046 & & $3 * * *$ & & 0.045 & & & \\
\hline (Std error) & & & $8.007 \times 10^{-4}$ & & & & $\int_{3}^{1.201 \times 10^{-}}$ & \\
\hline Distance from supply & $19.467^{* * *}$ & 15.339 & -1.643 & 0.094 & 0.002 & 0.105 & -3.977 & 1.018 \\
\hline $\begin{array}{l}\text { market } \\
\text { (Std error) }\end{array}$ & 1.269 & & 17.478 & & 0.019 & & 3.906 & \\
\hline Co-operative & $2.334^{* *}$ & 1.998 & $0.005^{* * *}$ & 2.63 & 0.090 & 0.474 & 4.912 & 0.886 \\
\hline $\begin{array}{l}\text { Membership } \\
\text { (Std error) }\end{array}$ & 1.168 & & 0.0019 & & 0.819 & & 5.544 & \\
\hline Unique Selling Device & $33.451^{* * *}$ & 2.599 & 1.994 & 0.228 & -0.782 & 0.940 & 0.0009 & 0.313 \\
\hline (label) & 12.867 & & 8.746 & & 0.832 & & 0.0029 & \\
\hline (Std error) & & & & & & & & \\
\hline $\mathrm{R}^{2}$ & 0.663 & & 0.587 & & 0.604 & & 0.543 & \\
\hline Adjusted R2 & 0.601 & & 0.553 & & 0.587 & & 0.501 & \\
\hline F-statistics & $7.279 * * *$ & & $5.258^{* * *}$ & & $5.645^{* * *}$ & & $4.396^{* * *}$ & \\
\hline No of Observation & 48 & & 48 & & 48 & & 48 & \\
\hline$* * *$ & & & Signif & nt @P $<$ & .01 critical le & & & \\
\hline$* *$ & & & Signif & nt @P $<$ & .05 critical le & & & \\
\hline$*$ & & & Signif & nt @P $<$ & 10 critical le & & & \\
\hline
\end{tabular}

\section{Source: Computed from SPSS 2018}

Again, exponential model has only four significant explanatory variable at $\mathrm{P}<0.05$ critical level. The semi-log and double log each has 5 significant explanatory variable at $\mathrm{P}<0.05$ critical level while the linear form has 6 significant explanatory variable at at $\mathrm{P}<0.05$ critical level. This means that the functional form has satisfied 3 out of the four criteria for selecting the lead equation hence, the linear model was chosen as the lead equation and it is specified as follows:

$\mathrm{C}_{\mathrm{ucom}}=193.26-0.003 \mathrm{X}_{1}+0.156 \mathrm{X}_{2}+0.007 \mathrm{X}_{3}-1.585 \mathrm{X}_{4}-5.782 \mathrm{X}_{5}{ }^{* *}+4.678 \mathrm{X}_{6}^{* * *}-$

$4.781 X_{7}{ }^{* * *}+19.467 X_{8}^{* * *}+2.334 X_{9}^{* * *}+33.451 X_{10}{ }^{* * *}$

$\mathrm{R}^{2}=0.663$

Adj $\mathrm{R}^{2}=0.601$

F-statistics $=7.279 * * *$ 
The lead equation has an $\mathrm{R}^{2}$ of 0.663 which implies that $66.3 \%$ explanation to variations in consumers' satisfaction (utility) compromise can be explained by the included explanatory variables. It could be seen from the model that trading as major occupation, number of years of trading experience, total marketing cost, distance from the supply market, co-operative membership and unique selling device employed by the retailer were all significantly different from zero at $\mathrm{P}<0.05$ critical level given their individual sizes of absolute $t$-value, which is greater than the tabulated t-value of 1.98 as shown in the result. Again, the result reveals that trading as the major occupation of the marketers and retail marketing cost were both significant and negative. This implies that a unit increase in each of the variable will lead to 5.782 and 4.781 unit reduction in consumers' satisfaction (utility) compromise along the raphia wine supply chain. Marketing cost must have an increasing effect on the marketing efficiency and marketing margin, which might increase the value added and consequently the value the consumer places on the product. This is not the same with the trading as the major occupation. If this variable increases, marketing activities and value addition increases thus causing an increase in consumer satisfaction (utility) compromise. The reason for this sharp contrast could be due to skill arts of major stakeholders and long relationship established between consumers and retail vendors who serve as major distributors in raphia wine supply chain.

The result further shows that number of years in the business, distance from the area of supply, co-operative membership and unique selling device employed by the retailer though significant are also positively related with consumer satisfaction (utility) compromise in the area. This implies that a unit increase in any of these variables will lead to 4.678 units, 19.467 units, 2.334 units and 33.451 units increase consumer satisfaction (utility) compromise respectively. Consumer satisfaction compromised will increase with distance from the market as most consumers cannot afford to cover the distance for a concentrated fresh raphia wine, hence any available wine becomes desirable and they can pay any amount offered to them by the retailers. In the same manner, co-operative membership will offer the retail vendors the needed protection in terms of price and availability of the product even when it is at the detriment of consumers' satisfaction. The retailers' co-operative membership may offer an opportunity of hoarding, thus making the product relatively scarce and consumers taking any price offered for sale. This suggest that consumer protection agencies should hold the cooperative societies responsible for any bridge of marketing inefficiency and reduction in consumers satisfaction or reduced quality of the product along the supply chain.

Furthermore, the result reveals that trading experience and unique selling device can increase consumer satisfaction (utility) compromise. Increase in trading experience may mean increase in skill, strategies and methods of increasing sales even if it is at consumers' detriment in the area. According to CES FUTO, (2013) noted that unique selling proposition provides product uniqeness and protect it against existing or new competitors. Raphia wine supply chain needs stakeholders who can identify the various constituent of each wine and be able to place standard accordingly. This might initiate consumer satisfaction (utility) compromise along the supply chain. Just as unique selling device like labels and brand names made by the retail vendors can create popularity among retail vendors and ensure regular patronage. According to Ekpeno (2002) trading experience ensures that raphia wine retail vendors have spent very long years in the business that the skill arts of the business has become their nature and part of them. The secret is only kept to protect the product from adulterations. This can create bad impression as any unsuspecting consumers who cashed on this unique selling proposition may not know with certainty when their satisfaction is tampered, hence paying for low quality may not be very common along such supply chain. This finding is consistent with the findings of Ekpeno (2002) who observed that consumers appear to know their regular vendors because of 
the unique component of the wine they sold. Hence, patronage base on the unique selling proposition may be misleading when quality is compromised.

Table 4: Distribution of Consumers based on their Complaints on raphia wine consumed in Imo State

\begin{tabular}{|c|c|c|}
\hline Variables & Frequency $^{+}$ & Percentages (\%) \\
\hline Wide product colour differentiations & 56 & 61.54 \\
\hline Wide differences in sugar level and taste & 72 & 79.12 \\
\hline Obvious changes in concentration of the sap & 69 & 75.82 \\
\hline Increased wine acidity & 48 & 52.75 \\
\hline Lack of safety nets and exposure to health hazards & 34 & 37.36 \\
\hline Use of different measuring Standards & 82 & 90.10 \\
\hline No organized markets and product labels & 86 & 94.51 \\
\hline Obvious health challenge after consumption & 30 & 32.97 \\
\hline Preference for brewed beer to raphia wine & 20 & 21.98 \\
\hline
\end{tabular}

\section{Source: Field survey 2018}

$(+=$ Multiple response)

Table 4 presents the distribution of consumers based on their different complains from wine consumed from retail outlets in the area. Majority (94.51\%) of the consumers complained that local wine marketing are not organized because the product does not have proper labeling or trademark from their origin. Such product may not have license and in case of any health problem arising from its consumption, the supplier may not be easily identified. This is followed by $90.0 \%$ of them that complained of no standardized measures for the product. This means that apart from the unorganized marketing system, the product may be sold at irregular units where consumers are not sure of the equal value for their money. The result shows that 79.12\% consumers complain for differences in sugar level and the taste of the product probably due to some mixtures with other substances during handling processes. This finding collaborates the observation of Amoa-Awua et al. (2007) and Ouoba et al. (2012) that wine from retail vendors may have differences in taste, colour, quality and quantity of the same product in the spatial markets. The result shows that relatively few $(21.98 \%)$ consumers prefers brewed products to raphia wine while about $32.97 \%$ and $37.36 \%$ of them complained that they observe health challenges after consumption and that the product lacks safety nets respectively. This shows that despite the unorganized marketing system, changes in colour, taste and concentration of the sap, majority still patronize local retail vendor of raphia wine and may be ignorant of consumers satisfaction comprise in the marketing system in the area.

\section{CONCLUSION AND RECOMMENDATION}

The need to ensure adequate value for agricultural product requires that consumers preference must be assessed and understood. This is not so with raphia wine marketing in Imo State. Raphia wine marketer ignores quality or rather compromises quality for maximum revenue. Consumers who are ignorant fall for these compromises. This could be the reason for high market inefficiency especially in the long run when the consumer may have the information of the activities along the supply chain. It was shown in this study that the consumer pay higher for quality already compromised, hence reducing his utility level ignorantly. The study showed that value addition to raphia wine distribution attracts higher revenue and profit and at the same time expands the marketing margin per unit of the product consumed. The study equally showed that despite the high marketing margin, the stake holders in the supply chain are better off but they have a greater percentage of their returns from some practices the consumers cannot place adequate value to. They may be playing on the consumers' satisfaction and the amount of satisfaction compromised by the consumer 
could be the major reason for market inefficiency in the supply chain in the area. The study therefore recommends the following:

i. Consumer protection council and standard organization of Nigeria should look into the raphia wine supply chain for organize and standardized products. This will ensure that quality is not compromised for revenue maximization and consumers get equal value for their product in the state.

ii. It is important to educate the market stakeholders on the importance of safety nets, quality distributions and imporatnace of ensuring good and healthy distribution of the product in the area.

iii. It is important retailer to identify a unique selling device that can guide their patronage. Unique selling device focuses on safety and quality as a trade mark for consumers' patronage. This will help the consumer to complain whenever their satisfaction is tampered with in the area.

iv. The raphia wine supply is very profitable and more stakeholders can take advantage of the high profit margin especially at the retail stage to ensure adequate supply is made and food security objective is achieved in the area.

\section{References}

Adegeye, A. J. And S. Dittoh (1982).Essentials of Agricultural Economics, Impact publishers Ibadan Nigeria pp120.

Adekunle, A. (1978) Modern analysis Economics,Aromolaran publishing company limited Ibadan, Nigeria . pp 12192.

Aiyeloja, A.A., Oladele, A.t \& Tumulo, O. (2014). Potential of Raphia hokeri wine in livelihood sustenance among rural and urban population in Nigeria. International Journal of Social, Behavioural, Educational, Economic and Management Engineering 8(7) 2316-2323

Ajakaye, R. (2015). Nigeria's palm wine. Retrived on September 23, 2015, from http://www.aa.com.tr/en/health/452887-nigeria-palm-wine

Ajayi, A.O., Bisi-Johnson M.A. \& Adejuwon A.O. (2011). Meddling with cultural heritage: Traces of salicylate I adultrated palm wine and health implications MA. African Journal of Food Science2011; 5: 536-540.

Ali, E.A \& Jampada, T.N. (2008). Economic Analaysis of fresh fish marketing in Maidugiri Gamboru Market and Kachallari Alau Dam landing site of Northeastern Nigeria. J. Agri. Soc. Sci.

Amerine, M.A.A. and R.E. Kunle (1958), Microbiology of wine making. Annual review, microbiology 22:323-355.

Amoa-Awua, W.K. Sampson, E. \& Tano-Debrah, K. (2007). Growth of yeast, lactic acid and acetic acid bacteria in palm wine during tapping and fermentation from felled oil palm tree Elaeis guineensis in Ghana. Journal of Applied Microbiology 102 (2): 599-606

Bartle, P. (2012). Abe (Oil palm) tapping. Available from www.scn.org/rdi/kw-abem.htm (Accessed 31 July, 2012).

Ehirim, N.C. (2010). Determinants of consumers' Preference for Safe Chicken Consumption in Imo State, Nigeria. Researcher 2010;2(12) http://www.sciencepub.net/researcher.

Ehirim, N.C., H.O. Mark, C. Ogueri, G. S. Adaka and T.T. Awoyemi (2007). “Determinants of Consumers Willingness to pay for Fish Safety Consumption in Batelsa State." The Social

Ekpeno, D.H. (2002). The stand of agriculture in Nigerian econmy. Production and characterization of wine from mangofruit (Mangifera indica). World Journal Biotechnology, 21: pp. 1345-1350.

Esechie, H.A.(1978).Effects of different preservatives on the major chemical constituents of bottled palm wine during storage. The Nigerian agricultural journal, 15(1):158-167.

Ezeagu, I.E. \& Fatunso, M.A. (2003). Biochemicval constituents of palm wine. Ecology and Food Nutrittion 42(1). pp.213-222.

Ezealaji, N.L.O (2011). Economics of palm oil storage and marketing in Imo State, Nigeria. African Journal of Marketing Management vol. 3(10), pp 252-260.

Faparusi, S.J. and O. Bassier (1972).The factors affecting the quantity of palm wine; period of tapping a palm tree. West African journal of biology and applied chemistry 15:17-23. 
Imo ADP (2013) News Reports of Imo State Agricultural Development Programme on Soil Management Techniques. pp. 12-18.

Karamako, D; Djeni, N.T., N'guessan, K.F., Bouatenin, K.M.J. \& Dje, K.M (2012). The biochemical and microbiological quality of palm wine samples produced at different periods during tapping and changes which occurred during their storage. Food Control 26(2): 504-511.

Kohl's J. L. And J. N. Uhl (1980) marketing of agricultural products.Macmillian publishers, New York, pp 1-10.

Li J.J \& Su, S. (2006). How face influences composition. A comparative study of American and Chinese consumers. International Journal of Market research, 49, 237-256.

MANR, (1998). Bulletin Reports of State Ministry of Agriculture and Natural Resources. Vol. 9. pp. 12-22.

Ndom, B.A. (2003). The Raphia palm. $1^{\text {st }}$ ed. Concept Publication, LTD, Mushin, Lagos, Nigeria. pp.1-30

NIFOR (1974/75). Eleventh annual report, NIFOR, 12 Benin city Nigeria pp88.

Noll, R.G. (2008). The wines of West Africa: history, technology and tasting notes. Wine Econ 3: 85-94.

Nwaibo, S.U., Odo N.E. \& Igbeli C.O. (2012) Economics analysis of palm wine marketing in idemili North Local Government area of Anambara State, Nigeria International Journal of Applied Research and Technology. 1(13): 3-9.

Obahiagbon, F.I \& Osagie, A.U. 2007). Sugar and micro-minerals composition of sap produced by Raphia hookeri palms. African Journal of Biotechnology, 6(6) 744-750

Obahiagbon, F.I (2009). A review of the origin, morphology, cultivation, economic products, health and physiological implication of paphia palm. African Journal of Food Science 3(13): 447-453.

Okolo E.C and Abigor R.D.(2006). Components of the stigmatic exudates of raphia hookeri. Mann and wendl. Journal of agriculture, forestry and the social sciences 4(2): 83-88.

Okolo, E.C \& Abigor, R.D. (2006). Components of exudates of Raphia hookeri. Journal of agricultureal, forestry and social sciences. 4(2): 347-352.

Oliver, R. L. (1996). Satisfaction: A behavioral perspective on consumer. New York: Prince Hill.

Olukosi J.O.And P.O. Erhabor (1985).Introduction to farm management economics,Agitab publication, Zaria Nigeria. 12-30

Olukosi, J.O. and U.U. Isitor, (1990).Introduction to agricultural marketing and prices, market structure analysis, living book series G. U. Publications. Pp2-6.

Omofonmwan, E.I, Ashaolu, O.F, Ayinde L.A. \& E. O. Fakoya (2013). Assessment of palm wine market in Edo State. Journal of Science and Multidiciplinary Research 5(2): 141-151.

Ouaba, L. Kando, C. Parkouda, C. Swadogo-Lingani, H. Diawara, B. \& Surtherland J.P. (2012). The microbiology of Banji, palm wine of Borassus akeassii from Burkina Faso: Identification and genotypic diversity of yeast, lactic acids and acetic acid bacteria. Journal of applied Microbiology 113(6): 1428-1444.

Scarbotough, V. \& Kydd, J. (1992). Economic analysis of of agricultural marketing: A manual. Chatham, Natural Resources Instt. UK pl 42.

Science 2(4) pp 399-404 Medwell Journals, 2007.

Stringini, M; Comitini, F; Taccari, M. \& Ciani, M. (2009). Yeast diversity during tapping and fermentation of palm wine from Cameroon, Food Micro Biology 26(4): 415-420.

Ugwu, S.O.C. \& Igoeli, G. (2009). Motality and Fertility capacity of boar semen stored in raphia palm (Raphia hookeri)

Unaeze, H.C., M.E. Onu \& Agumagu A.C. (2009). Economic Analysis of raphia Palm (Raphia hookeri) Production in Obio-Akpo Local Government area, Rivers State, Nigeria. Nigerian Journal of Farm management, FAMAN Journal 10(1). 